http://www.moderntechno.de/index.php/meit/article/view/meit06-03-035 DOI: 10.30890/2567-5273.2018-06-03-035

УДК 656.1 : 331

\title{
PERSONNEL MANAGEMENT IN CONDITIONS OF TRANSFORMATION CHANGE
}

ФІЛОСОФІЯ УПРАВЛІННЯ ПЕРСОНАЛОМ В УМОВАХ ТРАНСФОРМАЦІЙНИХ 3MIH

Melnichuk L.V./Мельничук Л.В. c.h.s., as.prof. / к.i.н., доu. State University of Telecommunications, st. Solomyanskaya 7, Kyiv Державний університет телекомунікаиій, м. Київ, вул. Солом'янська 7

Анотація. У статті розглянуто теоретичні основи понятя «управління персоналом». Проведена систематизація точок зору дослідників, щзо дозволила обгрунтувати різні взаємозв'язки в їх позиціях $i$ виділити підходи. Розглянуто закономірності й принципи формування сучасних систем управління персоналом на основі нового управлінського мислення. Визначено основні завдання управління персоналом на підприємствах в умовах трансформаційних змін.

Ключевые слова: персонал, кадрова політика, трансформачія, управління, економічний розвиток, розвиток організацій, філософія організації.

Менеджмент в будь-якій країні, відображає їі історичні особливості, культуру і суспільну психологію. Він безпосередньо пов'язаний з суспільно економічним укладом країни.

Як правило, історія розвитку управлінської думки випереджає процес вдосконалення системи управління на практиці. Тому, вивчаючи позитивний досвід системи управління, було б можливим знайти шляхи вдосконалення управління суспільним виробництвом в світі. Досвід в роботі 3 персоналом дозволяє виділити ті конкретні ідеї, здатні забезпечити і прискорити вихід економіки багатьох країн із кризи, дає можливість навчити працівника i керівника так, щоб він зміг направити свою економіку за потрібної траєкторії розвитку. [15]

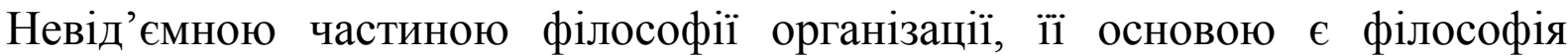
управління персоналом. Дотримання філософії гарантує успіх, добробут у взаємостосунках персоналу i, як наслідок, ефективний розвиток організації. Порушення філософських постулатів веде до розвитку конфліктів між адміністрацією і працівниками, до зниження ефективності функціонування організації, втраті їі іміджу і може призвести до банкрутства, оскільки персонал - це іiі головне надбання.

Філософія управління персоналом полягає не тільки в тому, щоб задовольнити потреби організації в укомплектовуванні персоналом, але і в тому, щоб як найповніші задовольнити потреби працівників. Це і є задачею системи управління персоналом організації (в найширшому філософському значенні). [7]

В економічній літературі не існує єдиного підходу до визначення сутності поняття «управління персоналом», а різні трактування підкреслюють різноманіття існуючих теоретичних підходів до управління персоналом, людськими ресурсами. 
Серед вчених, які присвятили наукові праці теорії та практиці управління персоналом, такі, як О.А. Грішнова, Г. Десслер, А.П. Єгоршин, Л.В. Карташова, А. Робертсон, В.О. Храмов [1-19] та ін.

Теоретико-методологічні основи оцінки персоналу активно досліджуються зарубіжними та вітчизняними науковцями, як А. Алавердов, М. Альберт, І.Ансофф, Д.Богиня, І.Булєєв, В.Веснін, О.Грішнова, В.Данюк, Г.Дмитренко, П. Друкер, А.Сгоршин, О.Сськов, Г.Завіновська, А.Кібанов, А.Колот, М. Мескон, I. Метцнер, Ю. Одегов, М.Семикіна, І. Хентце, Ф. Хетдоурі, І. Швець, С. Шекшня, Г.Щокін. Науково-методичне підгрунтя щодо управління персоналом у системі управління якістю присвячені дослідження О.Криворучко, Н.Михайлова, О.Момот, В.Панкова, В.Петюха, Г. Скударя, Є.Шубенкова, В.Шинкаренка. Теоретичні підходи до оцінки персоналу у готельному господарстві частково обговорювались О.Агаміровою, О.Бейдиком, А.Булгаковою, С. Гончаровою, В.Квартальновим, М. Кабушкіним, Л.Калініною, Г.Паперяном, Т.Пічутіною.

Враховуючи вагомий вклад вчених у розроблення проблематики управління персоналом, все ж таки, потрібно додатково зупинити увагу на завданнях та принципах управління персоналом підприємств в умовах трансформаційних змін.

Це і визначило мету даної статті. Філософія організації, як сукупність мети і правил поведінки співробітників виникла в Японії в крупних компаніях Mitsubishi, Toyota, Sony, а потім отримала широке розповсюдження в США в компаніях IBM, General Motors, McDonald's. А. Моріта, президент корпорації Sony, так сформулював філософські принципи підприємства нового типу: «Якби вдалося створити умови, в яких люди могли б об'єднатися 3 твердим наміром спільно працювати i використати свої технічні здібності для здійснення своїх сокровенних бажань, то така організація могла б принести величезну насолоду і користь». Ці принципи включають:

1) вибір головної мети і постановка науково-технічних задач;

2) патерналізм - виховання у зайнятих на фірмі відчуття, що вони члени однієї сім'ї (довічне наймання співробітників, неординарні форми спілкування 3 керівництвом, планування службової кар'єри, фірмовий одяг );

3)розвиток творчої ініціативи та свідома відмова від складання жорстких планів.

Українська філософія управління персоналом досить багатоманітна i залежить від форми власності, регіональних і галузевих особливостей та розміру організації. Крупні акціонерні організації, створені на базі державних, зберігають колишні традиції $\mathrm{i}$ характеризуються чіткою дисципліною, колективізмом i господарністю, передбачають підвищення рівня життя працівників i збереження соціальних благ i гарантій в нових умовах господарювання.

Управління персоналом організації підкоряється ряду закономірностей: відповідність системи управління персоналом меті, особливостям, стану i тенденціям розвитку виробничо-господарської системи, вимогам виробництва; необхідність обліку взаємозв'язків між підсистемами і елементами у середині 
системи управління персоналом; оптимальне поєднання централізації i децентралізація управління персоналом; 3 розвитком організації змінюється склад і зміст функцій управління персоналом; закономірність мінімізації рівнів управління персоналом[8].

Враховуючи зазначені закономірності, до основних принципів управління персоналом - правил, основних норм, яким повинні слідувати керівники в процесі управління персоналом, відносять [2]:

- принцип єдності розпорядництва; принцип поєднання єдиноначальності i колегіальності;

- поєднання централізації і децентралізації; контролю виконання рішень; відбору, підбору і розстановки кадрів тощо.

Функції управління персоналом тісно зв'язані між собою і утворюють в сукупності певну систему роботи з персоналом, де зміни, що відбуваються у складі кожної з функцій, викликають необхідність коректування всіх інших зв'язаних функціональних задач і обов'язків. За таких умов найму, природно, підвищується значення функціональних обов'язків, пов'язаних із забезпеченням трудових відносин, вирішення соціальних питань, розширяється коло обов'язків в рамках функцій найму, працевлаштування, матеріальної винагороди.

Особливості трансформаційних періодів потребують більш пильної уваги до персоналу, бо за своїм змістом вони $є$ вихідною точкою або базою для кожного наступного за ним етапу розвитку. Трансформація внутрішнього середовища, що залишалося довгий час стабільним, в плані очікування неминучих змін і непередбачуваних наслідків процесів змін негативним чином позначається не тільки на соціально-психологічному кліматі трудового коллективу, але i на ефективності діяльності персоналу i результатах функціонування підприємства, викликає опори трудового коллективу організаційним змінам.

Все це, слід врахувати, при розробці комплексу соціально-економічних заходів щодо проведення реформування підприємств та вимагає коректування загальних принципів кадрового менеджменту. Так, принципи управління персоналом підприємств у період трансформацій мають враховувати високі ризики кадрової безпеки, що виникає в результаті опору змінам. [4]

Принципи управління персоналом в умовах трансформаційних змінПринцип інформаційної прозорості свідчить про те, що ефективне управління людськими ресурсами можливо лише при формуванні максимально прозорого для персоналу інформаційного середовища щодо мети, етапів процессу змін і кадрової політики на період нестабільності внутрішнього середовища. Забезпечення об'єктивної оцінки обумовлено тим, що в умовах трансформаційних змін керівництву необхідно володіти повною об'єктивною інформацією про кадровий потенціал підприємства, трудовий потенціал кожного працівника, ефективність його діяльності і корисність в нових умовах функціонування підприємства. Принцип оптимальностіперсоналу полягає в необхідності його оптимізації (як щодо кількості, так і якості ).

Найважливіше місце в ході трансформаційних змін займають менеджери, що набувають на період трансформації підприємств нові якості, які повинні 
чітко відповідати конкретному етапу змін [17].

Застосування принципу соціально-психологічної підтримки обумовлено тим, що широкомасштабні зміни, які відбуваються в процесі трансформацій підприємств викликають стійке відчуття нестабільності персоналу і це вимагає додаткової безперервної роботи 3 підтримки стабільного, сприятливого психологічного клімату в трудовому колективі. Зміна виробничої структури $\mathrm{i}$ технологічних процесів, обумовлені трансформаціями, ускладнюють управління персоналом, що засноване на використанні переважно економічних методів. Дана обставина обумовлює застосування мотивації працівників господарюючого суб'єкта, заснованої на персональному та/або коллективному досягненні конкретної мети в процесі трансформації, що свідчить про необхідність врахування такого принципу, як зміна мотиваційних інструментів, їх узгодження з метою конкретних етапів змін.

Врахування представлених вище принципів управління персоналом підприємствами в умовах їх реформування орієнтовано на швидше досягнення бажаних результатів кадрової політики і зможе забезпечити належний рівень соціально-економічної безпеки господарської діяльності в цілому. Важливим $\epsilon$ те, що поряд з розширенням принципів в умовах трансформацій підприємств відбувається і розширення завдань управління персоналом. Найслабкіша ланка в системі безпеки підприємства - це його кадрова.

Забезпечення кадрової безпеки проводиться за такими основними напрямками :

-вдосконалення підходів до підбору кандидатів на вакантніпосади;

-вивчення і аналіз лояльності персоналу ;

-профілактика можливих порушень з боку персоналу. [1]

Можна виділити наступні завдання управління персоналом в межах представлених напрямків :

1) вивчення працівників, які наймаються на роботу, щодо їх минулої трудової діяльності ;

2) бесіди з тими, хто наймається на роботу в підрозділи, робота яких пов'язана 3 комерційною таємницею, з метою встановлення їх придатності для цієї роботи;

3) оформлення зобов'язань про нерозголошування відомостей, що становлять комерційну таємницю;

4) аналіз і облік трудової задоволеності 3 метою попередження звільнення співробітників, допущених до інформації, що належить до комерційної таємниці;

5) організація навчання співробітників 3 питань захисту комерційної таємниці;

6) аналіз та оцінка компетентності співробітників;

7) бесіди з тими, хто звільняється, для оцінки та аналізу кадрової ситуації.

Трансформаційні процеси на сучасних підприємствах часто супроводжуються значним вивільненням i, отже, перерозподілом робочої сили, збільшенням числа працівників, змушених або освоювати нові професії, або 
змінювати своє робоче місце i колектив, тому набувають актуальності вирішення завдань адаптації персоналу, що включають : організацію семінарів, курсів з різних питань адаптації; проведення індивідуальних бесід керівника, наставника 3 новим співробітником; інтенсивні короткострокові курси для керівників; спеціальні курси підготовки наставників; використання методу поступового ускладнення виконуваних новачком завдань; виконання разових громадських доручень для встановлення контактів нового працівника 3 коллективом; підготовка заміни при ротації кадрів; проведення в колективі спеціальних рольових ігор по згуртуванню співробітників. [12]

Перехід до нових умов роботи підприємств визнаає необхідність приділення уваги вирішенню завдань соціального захисту працівників, які стосуються:

1) забезпечення соціальних гарантій і соціального захисту персоналу, в тому числі: організація перепідготовки працівників, що вивільняються i переходять на іншу роботу, сприяння в працевлаштуванні працівників, що вивільняються;

2) зниження соціально-психологічної напруги в колективі, яка викликана невизначеністю і неінформованістю. [1]

Поряд із зазначеним вище необхідно вирішити також завдання щодо збереження та розвитку людського потенціалу підприємства, що потребує: виявлення високопотенційних співробітників, формування кадрового резерв; створення корпоративної системи навчання і контролю ефективності окремих навчальних заходів. Таким чином, визначено основні завдання управління персоналом на підприємствах в умовах трансформаційних змін.

Реалізація цих завдань, в першу чергу, потребує формування кадрової політики, де дані положення мають бути зафіксовані та використовуватися як орієнтир в роботі з управління персоналом.

Література:

1. Науково -технічний збірник № 104 2821. Грішнова О.А. Оцінювання персоналу : сучасні підходи до забезпечення ефективності / О.А. Грішнова, О.О. Наумова // Формування ринкової економіки: 3б. наук. пр. - Т.2 :Управління персоналом в організаціях . - К.: КНЕУ, 2005. - С.42-50.

2. Балабанова Л.В. Організація праці менеджера: навч. посіб./ Л.В.Балабанова, О.В. Сардак. - К.: Професіонал, 2004. - 304c.

3. Гегель Г.В. Работы разных лет: В 2 т. - М., 1971.

4. Лебедев В. Китайская философия управления, не имеющая себе равных/ Серия очерков о Китае, Вестник №9(163).

5. Михайлова Л.І. Управління персоналом. Навч. посібник. - К.: Центр учбової літератури, 2007. - 248с.

6. Пазенок В.С. Філософія: Навч. посіб. - К.: Академвидав, 2008. - 280с.

7. Управління людськими ресурсами: філософські засади. Навч. посібник. Під ред. В.Г. Воронкової; [В.Г.Воронкова, А.Г.Беліченко, О.М. Попов та ін.] К.: Професіонал, 2006. - 567c.

8. Управління як соціальний феномен. О.Б.Гаєвська.- К.:КНЕУ, 2000. - 
$168 \mathrm{C}$.

9. Хамітов Н., Гармаш Л., Крилова С. Історія філософії. Проблема людини та іiі меж. Навчальний посібник зі словником/Під ред. Н. Хамітова. 2-е вид. - К.: КНТ, Центр навчальної літератури, 2006. - 296с.

10. Хамітов Н., Крилова С. Философский словарь. Человек и мир. - К.: КНТ, Центр навчальної літератури, 2008. - 311с.

11. Хамітов Н. Философия. Бытие. Человек. Мир: Курс лекций. - К.: КНТ, Центр навчальної літератури, 2006. - 456с.

12. Щокін Г. Закони соціального розвитку і управління.- К.: МАУП, 2006. $-189 \mathrm{C}$.

13. Балабанова Л. В. Управління персоналом : підручник / Балабанова Л. В., Сардак О. В. - К. : Центр навч. л-ри, 2011. - 468 с.

14. Богоявленська Ю. В. Економіка та менеджмент праці : навч. посіб. / Ю. В. Богоявленська, С. І. Ходаківська. - К. : Кондор, 2006. - 366 с.

15. Десслер Г. Управление персоналом / Г. Десслер; под общ. ред. И.М. Степнова; пер. с англ. - М.: БИНОМ. Лаборатория знаний, 2004. - 799 с.

16. Егоршин А.П. Основы управления персоналом / А.П. Егоршин. - 2-е изд., перераб. И доп. - М.: ИНФРА - М, 2008. - 352 с.

17. Карташова Л. В. Управление человеческими ресурсами / Л.В. Карташова; Ин-т экономики и финансов "Синергия". - М.: ИНФРА - М, 2009. $234 \mathrm{c}$.

18. Робертсон А. Управление талантами. Как извлечь выгоду из таланта ваших подчиненных / А. Робертсон, Э. Грэм: пер. с англ . - Днепропетровск: Баланс -Клуб, $2004-200$ с.

19. Храмов В.О. Основи управління персоналом / В.О. Храмов, А.П. Бовтрук. - К.: МАУП, $2001-112$ с.

\section{References:}

1. Scientific and technical collection No. 104 2821. Grishnova O.A. Assessment of staff: modern approaches to ensuring efficiency / O.A. Grishnova, O.O. Naumova // Formation of market economy: Zb. sciences пр. - T.2: Personnel management in organizations. - K.: KNEU, 2005. p.42-50.

2. Balabanova L.V. Organization of labor manager: teacher. manual / L.V.Balabanova, O.V. Sardak - K.: Professional, 2004. - 304s.

3. Hegel G.V. Works of different years: In 2 t. - M., 1971.

4. Lebedev B. Chinese philosophy of governance, not having equal / A series of essays on China, Herald No. 9 (163).

5. Mikhailova L.I. HR. Teaching manual. - K.: Center for Educational Literature, 2007. 248s.

6. Pazenok V.C. Philosophy: Teaching. manual - K .: Akademvidav, 2008. - 280s.

7. Management of human resources: philosophical principles. Teaching manual. Ed. VG Vonkova; [V.G.Voronkova, A.G.Belichenko, O.M. Popov et al.] - K .: Professional, 2006. - 567s.

8. Management as a social phenomenon. O. B. Hayevskaya. - K .: KNEU, 2000. - 168C.

9. Hamitov N., Garmash L., Krylova S. History of philosophy. The problem of man and its boundaries. A manual with a dictionary / Ed. N. Khamitova 2nd view. - K .: CST, Center for Educational Literature, 2006. - 296s.

10. Hamitov N., Krylova S. Philosophical dictionary. Man and the world. - K .: CST, Center for Educational Literature, 2008. - 311p. 
11. Khamitov N. Philosophy. Being Man World: Course of lectures. - K .: CST, Center for Educational Literature, 2006. - 456s.

12. Shokin G. Laws of Social Development and Management. - K .: MAUP, 2006. - 189C.

13. Balabanova L.V. Personnel Management: Textbook / Balabanova L.V., Sardak O.V. - K.: Center for Teachers. L-ry, 2011. - 468 pp.

14. Bogoyavlenska Yu. V. Economics and Labor Management: Teach. manual / Yu. V. Bogoyavlenskaya, E. I. Khodakivska. - K.: Condor, 2006. - 366 pp.

15. Dessler G. Personnel Management / G. Dessler; in common. Ed. IM Stepnova; per. from english - M .: BINOM. Laboratory of Knowledge, 2004 - 799 pp.

16. Egorshin A.P. Fundamentals of Human Resources Management / AP Yegorshyn - 2nd ed., Pererab. And add - M .: INFRA - M, 2008. - 352 p.

17. Kartashova L.V. Human Resources Management / L.V. Kartashova; Institute of Economics and Finance "Synergy". - M .: INFRA - M, 2009. - 234 p.

18. Robertson A. Talent Management. How to benefit from the talents of your subordinates / A. Robertson, E. Graham: Per. from english - Dnipropetrovsk: Balance-Club, 2004 - 200 p.

19. Khramov VO Fundamentals of Human Resources Management / VO Temples, AP Umbilical cord - K .: MAUP, 2001 - 112 p.

Abstract. The article deals with the theoretical foundations of "personnel management". The systematization of the points of view of researchers was carried out, which allowed to substantiate different interrelations in their positions and to allocate approaches. Laws and principles of formation of modern systems of personnel management on the basis of new managerial thinking are considered. The basic tasks of personnel management at enterprises in the conditions of transformation changes are determined.

Key words: personnel, personnel policy, transformation, management, economic development, organization development, philosophy of organization.

Статья отправлена: 22.12.2018 г.

(C) Мельничук Л.В. 